\title{
Long-term macrolide antibiotics in asthma therapy
}

Daisuke Takekoshi ${ }^{1}$, Patrick Belvitch ${ }^{1}$, Israel Rubinstein ${ }^{1}$

1 Section of Pulmonary, Critical Care, Sleep and Allergy Medicine, Department of Medicine, College of Medicine, University of Illinois at Chicago and Jesse Brown VA Medical Center, Chicago, Illinois, U.S.A.

\section{Abstract}

Macrolide antibiotics drew worldwide attention when their use was dramatically successful in the treatment of diffuse panbronchiolitis in 1980s. The success was attributed to their immunomodulatory effects, rather than their antimicrobial properties. Since then, studies have shown that macrolides exert their immunomodulatory effects through several mechanisms, including suppression of proinflammatory cytokines, promoting apoptosis of inflammatory cells, improving phagocytic function, ameliorating airway hypersecretion, and inhibiting production of reactive oxygen species. Macrolides have also been studied in the treatment of asthma. This review highlights the role of macrolides in the treatment of asthma, presenting an overview of the main clinical trials. Despite favourable preclinical data and reports of anecdotal successes, the results of clinical trials are conflicting. This may be due to the heterogeneous nature of asthma. Further studies are needed to identify particular subgroup of asthma that will respond to macrolides.

\section{Keywords}

Macrolide; Asthma; Chronic inflammation; Immunomodulation; Noneosinophilic asthma 


\section{Introduction}

Macrolides consist of an expansive family of compounds characterised by the presence of a macrocyclic lactone ring. Interestingly, two broadly used immunosuppressive agents, silorimus (rapamycin) and tacrolimus (FK-506), are also members of macrolide family. However, these agents are not included when we use the term "macrolides" in this review unless otherwise indicated.

Macrolides are classified according to the size of the lactone ring. Erythromycin-derived 14- and 15-member macrolides draw particular interest due to their immunomodulatory function [1]. The immunomodulatory effect first drew considerable attention in the 1980s when long-term low-dose erythromycin treatment achieved large success in the treatment of diffuse panbronchiolitis [1]. Diffuse panbronchiolitis is a disease that is almost exclusively found in East Asia, especially in Japan. It is characterised by chronic cough, chronic sinusitis, sputum production, and progressive dyspnoea that eventually lead to respiratory failure and death. This was previously a commonly fatal disease with a five year survival rate of only $63 \%$. The survival rate has improved to more than $90 \%$ since the introduction of long-term low-dose erythromycin treatment [1-3]. This dramatic success was attributed to its immunomodulatory effects rather than its antimicrobial effect, because clinical improvement has been reported regardless of the state of chronic infection and despite the observation that antibiotic concentrations were frequently well below the minimum inhibitory concentration of several pathogenic bacteria [4]. Persistent airway colonization with bacteria despite the improvement was also demonstrated.

Given this success, large efforts have been devoted to elucidate the mechanism of macrolide immunomodulatory effects. Clinically, macrolides have also been employed to treat other chronic inflammatory lung diseases, including cystic fibrosis, bronchiectasis, chronic obstructive pulmonary disease (COPD), post-transplantation bronchiolitis obliterans, chronic rhinosinusitis, and asthma, with varied results. In this review, we will first outline the current understanding of asthma pathogenesis. Next, we summarise how macrolides affect the immune system in the context of asthma. Finally we present an overview of the results of clinical trials, and speculate on future directions for investigation.

\section{Pathogenesis of asthma}

Asthma is a chronic inflammatory disease of the airways, characterised by airflow obstruction and bronchial hyper-responsiveness. Autopsy and biopsy studies demonstrate airway infiltration with lymphocytes, eosinophils, and degranulated mast cells, denudation of airway epithelium, sub-basementmembrane collagen deposition, and goblet cell hyperplasia [5]. Neutrophil infiltration is also seen in certain subgroups of patients [6-8]. An abnormal immune response, mediated by type 2 helper (Th2) cells, underlies this complex inflammatory process [9]. When a genetically susceptible individual is exposed to a certain antigen, the antigen is taken up, processed, and presented by antigen presenting cells such as dendritic cells. Upon stimulation by antigen presenting cells, Th2 cells excrete various cytokines and promote the immune reaction characteristic of asthma. The major cytokines excreted from Th2 cells are IL-4, IL-5, IL-6, IL-9 and IL-13 $[5,10]$. These cytokines stimulate IgE production by $\mathrm{B}$ cells. IgE binds to IgE receptors on mast cells. Mast cells are located mainly on the epithelial surface areas of the body such as bronchial mucosa. Cross linkage of the mast cell bound IgE by the antigen causes degranulation of the mast cells and release of preformed and newly formed bioactive mediators, including histamine and leukotrienes which in the lung cause bronchoconstriction and glandular secretion. Mast cells also produce several cytokines, including IL-1, IL-2, IL-3, IL-4, IL-5, granulocyte-macrophage colony-stimulating factor, interferon- $\gamma$, and tumor necrosis factor, which promote proliferation and survival of $\mathrm{T}$ cells, eosinophils, and mast cells (positive feedback) and contribute 
to persistence of the inflammation. Cytokines produced by Th2 and mast cells promote eosinophil proliferation and infiltration. Activated eosinophils produce inflammatory proteins, including major basic protein, eosinophil-derived neurotoxin, peroxidase, and cationic protein. Reactive oxygen species are also produced. These chemicals directly injure airway epithelium. Eosinophils also produce leukotrienes, which contract airway smooth muscles, increase vascular permeability and may recruit more eosinophils [5,9-11].

The airway epithelial cells play an important role in initiation and maintenance of the inflammation in asthma [10,11]. Tight junctions between asthmatic epithelial cells are disrupted and allow easier entry of allergens and microbes into the subepithelial space, which leads to immune activation. Activated epithelial cells produce chemokines, such as eotaxin-1 and -2, RANTES and monocyte chemotacticproteins-3 and -4 , which attract eosinophils, lymphocytes, and mast cells. Airway epithelial cells also produce nitric oxide, which contributes to airway inflammation [9].

The end result of these processes is persistent inflammation of the airways leading to airflow obstruction and bronchial hypersensitivity. If these processes are allowed to persist, airway remodelling characterized by subepithelial thickening and smooth muscle hyperplasia and hypertrophy ensues [10]. These changes result in irreversible airflow obstruction.

Recently, the contribution of neutrophilic inflammation in asthma is drawing special attention $[6-8,12]$. It is not uncommon and is often seen in patients with severe and poorly controlled asthma. Neutrophils are the most common inflammatory cells seen in adult asthma exacerbations.

\section{Macrolide effects in asthma}

Major macrolides immunomodulatory effects relevant to asthma are summarized in Table I.

\section{Cytokines}

A number of studies since the 1990s have demonstrated that administration of various macrolides suppresses proinflammatory cytokine production in asthma and non-asthma, ex vivo and in vivo, both in animal and human subjects [13-71]. Proinflammatory cytokines in the lung demonstrated to be suppressed by macrolides include IL-1, 2, 3, 4, 5, 6, 8, 10, 13, TNFa, eotaxin, GM-CSF, RANTES, CCL20 (CTACK), CCL27 (MIP-3a), MIP-2, and VEGF. As noted above, Th2-type cytokines (IL-4, 5, 6, 9, and 13), especially IL-5 as an eosinophil promoter,

\begin{tabular}{|lc|}
\hline \multicolumn{1}{|c|}{ Immunomodulatory effect } & Reference \\
\hline Suppression of proinflammatory cytokines & $13-71$ \\
$\begin{array}{l}\text { Promote apoptosis of neutrophils and } \\
\text { lymphocytes }\end{array}$ & $74-82$ \\
$\begin{array}{l}\text { Improve amount and quality of airway } \\
\text { secretion }\end{array}$ & $73,87-92$ \\
Improve phagocytotic function & $72,83-85$ \\
Antimicrobial effect & $93-95$ \\
Suppresses ROS/NOS production & $107-113$ \\
\hline
\end{tabular}

Table I. Immunomodulatory effects of macrolides

play a major role in pathogenesis of asthma.

Noma et al. collected peripheral blood $\mathrm{T}$ cells from paediatric asthmatic patients who were sensitized by Dermatophagoides farimae and demonstrated roxithromycin suppressed antigen-stimulated $\mathrm{T}$ cell proliferation and production of IL-4 and IL-5 in a dose dependent fashion [13]. Lyn et. al similarly demonstrated azithromycin suppressed IL-5 production by T cells from asthmatic children ex vivo [14]. Beigelman et al. used an ovalbumin-sensitized mouse model of asthma and demonstrated that azithromycin attenuated leukocytosis in bronchoalveolar lavage (BAL) caused by antigen administration [15]. Furthermore, analysis of the BAL leukocyte differential demonstrated that azithromycin attenuated all inflammatory cell types including eosinophils, macrophages, lymphocytes, and neutrophils. However, the largest fold-reduction was noted in eosinophils. BAL cytokine levels of IL-5 and 
IL-13, as well as chemokines, CCL2 (also known as monocyte chemotactic protein-1, MCP-1), CCL3 (also known as macrophage inflammatory protein-1 $\alpha$, MIP-1 $\alpha$ ), and CCL4 (also known as macrophage inflammatory protein-1 $\beta$, MIP- $1 \beta$ ) were also suppressed. Amayasu et al. showed asthmatic human subjects treated with $200 \mathrm{mg}$ of clarithromycin twice daily for 8 weeks had significantly decreased blood and sputum eosinophils [16].

Even though these data indicate that macrolides do suppress Th2-type cytokines (IL-4,5, 6, and 13), the immunomodulatory effect of macrolides is most established in their suppression of IL-8 and TNF- $\alpha$ which are more closely linked with neutrophilic inflammation. Simpson et al. demonstrated that clarithromycin $500 \mathrm{mg}$ twice daily can suppress IL-8 levels, neutrophil accumulation and activation in the airways in patients with noneosinophilic asthma [17]. It is increasingly known that non-eosinophilic asthma is common and neutrophilic inflammation plays an important part in the pathogenesis of this asthma variant $[6-8,12]$. Studies have demonstrated that neutrophilic inflammation is more resistant to corticosteroid treatment, and elevations of IL-8 level are found in these patients. Additionally, common irritants associated with asthma exacerbations such as air pollution, bacterial endotoxins, viral infections, and ozone, also cause neutrophilic inflammation [12]. Therefore, macrolides are attractive agents that may prove efficacious in both noneosinophilic and irritant asthma.

\section{Survival of inflammatory cells, hypersecretion and phagocytosis}

The mechanism of persistent inflammation in asthma is unclear. However, it has been proposed that pre-programmed apoptosis and the phagocytosis of these apoptotic cells by macrophages (efferocytosis) play an important role in the resolution of inflammation [72,73]. Mucus hypersecretion and cilliary dysfunction, which are characteristic of asthma, also impair clearance of the inflammatory cells which provides a nidus for bacterial colonization that further promotes persistence of inflammation [72]. Macrolides may work on each component of these processes.

There is some evidence showing that macrolides can promote apoptosis of neutrophils and lymphocytes. Erythromycin, roxithromycin, clarithromycin, and azithromycin are shown to promote neutrophil apoptosis [74-76]. Suppression of lymphocytic survival is also shown in azithromycin and roxithromycin [77-79]. Some studies also suggest that macrolides may influence eosinophil survival $[80,81]$. However, it is not clear if these effects are through direct effects or above-mentioned suppression of cytokines and growth factors. Interestingly, some researchers have reported enhanced apoptosis in bronchial smooth muscle cells [82].

Clearance of the apoptotic cells is mainly carried out by macrophages (efferocytosis). Disturbance of this process can lead to secondary necrosis of inflammatory cells and exacerbation and persistence of inflammation. In COPD (chronic obstructive pulmonary disease), there is evidence that this pathologic process is important [72]. In asthma, the evidence is scarce, but Huynh et al. did demonstrate fewer phagocytic bodies in BAL from patients with severe asthma compared with control patients or patients with mild to moderate asthma [83]. They also demonstrated that macrophages from patients with severe asthma have decreased phagocytotic function in vitro. Together, these data indicate that this pathologic process may also play a role in asthma. Macrolides were shown to improve phagocytotic function of alveolar macrophages in healthy volunteers [84] and in COPD patients [85]. Therefore, macrolides may improve clearance of inflammation by improving inflammatory cell clearance via phagocytosis.

Airway mucus hypersecretion is an important pathophysiological feature of asthma. Excessive mucus can obstruct airways and impairs clearance of inflammatory cells which leads to persistence of inflammation $[73,86]$. Macrolides decrease mucus secretion via several mechanisms such as suppression of NF-kB, cytokine production, and direct inhibition of chloride channels [87-89]. Macrolides not only 
decrease the amount of secretion but also alter the rheological character of the mucus and making it easier to expectorate [90-92].

\section{Chronic infection}

Macrolides may also improve asthma through their intrinsic antimicrobial effect. Persistent atypical bacterial infections, especially with Chlamydophila pneumoniae and Mycoplasma pneumoniae, have been implicated in the pathogenesis of asthma. Martin et al. examined clinical specimens from the nasopharynx, the oropharynx, and the lung (BAL, brushing, and endobronchial biopsy) for the presence of clamydial or mycoplasmal infection from 55 stable asthmatic patients and 11 healthy controls in the United States [93]. Thirty-one asthmatic patients (56.4\%) were found to have positive PCR results for either M. pneumoniae (25 patients or 45.5\%) or C. pneumoniae (6 patients or 10.9\%). A study from Turkey also reports higher rates of PCR positivity for $C$. pneumoniae in stable asthmatic patients compared with healthy subjects [94]. These data suggest that chronic atypical bacterial infection is common in asthmatic patients and it may contribute to the pathogenesis of asthma.

Macrolides are well known for their superior coverage of atypical organisms. Simply eradicating chronic infection through the use of macrolides, therefore, may significantly improve asthma control in these patients. Kraft et al. conducted a randomized placebo-controlled trial of clarithromycin treatment in 55 stable asthmatic patients [95]. All of the patients underwent bronchoscopy and were evaluated for C. pneumoniae and/or M. pneumoniae PCR positivity. Clarithromycin treatment resulted in a significant improvement in the FEV ${ }_{1}$ only in the PCR-positive subjects $(2.50 \pm 0.16 \mathrm{l}$, to $2.69 \pm 0.19 \mathrm{l}$, mean \pm SEM; $\mathrm{p}=0.05$ ). Clarithromycin-treated PCR positive patients also demonstrated a greater reduction in inflammatory cytokines in the lung than PCR-negative patients.

\section{Viral infection}

Viral infection is a major cause of asthma exacerbations (80-85\% in children, $70-75 \%$ in adults [96]). There is some evidence that macrolides can ameliorate respiratory viral infection [97-103]. However, there are few data about macrolide effect specifically on virus-induced asthma exacerbation. One randomized controlled trial evaluated a group of patients with asthma exacerbation of whom $60 \%$ had serological evidence of Mycoplasma or Chlamydiophila infection. In this population, telithromycin treatment did demonstrate a decrease in asthma symptom scores [104]. While many of these patients may have had viral infections, it is difficult to assess the specific benefit of macrolides in regards to viral infection in this study.

\section{Reactive oxygen/nitrogen species (ROS/RNS) production}

ROS/RNS are produced by inflammatory cells (neutrophils, eosinophils, and alveolar macrophages) and contribute to airway inflammation in asthma $[105,106]$. Data suggest that macrolides interfere with ROS/RNS production [107-113]. For example, Borszcz et al. demonstrated that the human eosinophil and neutrophil respiratory burst was inhibited by up to 54\% with clarithromycin [113].

\section{Clinical trials}

Despite the above mentioned promising results from various experimental models and anecdotal successes, clinical trials are somewhat disappointing. A summary of randomized controlled trials is presented in Table II. 


\begin{tabular}{|c|c|c|c|c|}
\hline $\begin{array}{c}\text { Author, } \\
\text { year [ref.] }\end{array}$ & Patients & $\begin{array}{l}\text { Study design/ } \\
\text { interventions }\end{array}$ & Main outcomes & Note \\
\hline $\begin{array}{l}\text { Nelson, } \\
1993 \text { [117] }\end{array}$ & $\begin{array}{l}75 \text { adult } \\
\text { patients } \\
\text { with steroid- } \\
\text { dependent } \\
\text { asthma }\end{array}$ & $\begin{array}{l}\text { Double-blinded, } \\
\text { randomized, placebo- } \\
\text { controlled study. } \\
\text { Troleandomycin plus } \\
\text { methylprednisolone vs. } \\
\text { methylprednisolone alone }\end{array}$ & $\begin{array}{l}\text { No difference in steroid dose reduction } \\
\text { More steroid-related adverse events in } \\
\text { troleandomycin group }\end{array}$ & $\begin{array}{l}\text { See note from } \\
\text { Kamada, } 1993 \\
\text { section }\end{array}$ \\
\hline $\begin{array}{l}\text { Kamada, } \\
1993 \text { [115] }\end{array}$ & $\begin{array}{l}18 \text { children } \\
\text { with severe, } \\
\text { steroid- } \\
\text { requiring } \\
\text { asthma }\end{array}$ & $\begin{array}{l}\text { Double-blinded, } \\
\text { randomized, 3-arm } \\
\text { parallel study. } \\
\text { Troleandomycin plus } \\
\text { methylprednisolone } \\
\text { vs. troleandomycin } \\
\text { plus prednisone vs. } \\
\text { methylprednisolone only }\end{array}$ & $\begin{array}{l}\text { No difference in pulmonary function nor } \\
\mathrm{PC}_{20} \text {-methacholine between } 3 \text { treatment } \\
\text { arms. } \\
\text { Significant decrease in steroid } \\
\text { requirement in all treatment arms } \\
\text { compared within the groups vs. } \\
\text { baseline. Only significant difference } \\
\text { noted between troleandomycin } \\
+ \text { methylprednisolone group and } \\
\text { methylprednisolone only group: } 80 \% \pm \\
6 \% \text { vs. } 44 \% \pm 14 \% \text {, respectively }\end{array}$ & $\begin{array}{l}\text { Troleandomycin is } \\
\text { noted to increase } \\
\text { bioavailability of } \\
\text { methylprednisolone } \\
{[121] \text { and also }} \\
\text { reduce elimination } \\
\text { of theophylline } \\
{[122,123]}\end{array}$ \\
\hline $\begin{array}{l}\text { Shoji, } 1999 \\
\text { [118] }\end{array}$ & $\begin{array}{l}14 \text { adult } \\
\text { patients } \\
\text { with mild to } \\
\text { moderate } \\
\text { aspirin- } \\
\text { intolerant } \\
\text { asthma }\end{array}$ & $\begin{array}{l}\text { Double-blinded, } \\
\text { randomized, crossover } \\
\text { study } \\
\text { Roxithromycin } 150 \mathrm{mg} / \\
\text { bid vs. placebo, for } 8 \\
\text { weeks }\end{array}$ & $\begin{array}{l}\text { No improvement in PFT. } \\
\text { Improvement in symptom score. } \\
\text { Decrease in blood eosinophils and ECP } \\
\text { (roxithro vs. placebo: } 12.4 \pm 2.3 \text { vs. } 42.8 \\
\pm 7.6 \times 10^{4} / \mathrm{ml}, 3.6 \pm 1.4 \text { vs. } \\
14.8 \pm 7.6 \mathrm{mg} / \mathrm{l} \text { ) } \\
\text { Decrease in sputum eosinophils and ECP } \\
\text { (roxithro vs. placebo: } 10 \pm 6 \times 10^{4} / \mathrm{ml} \text { vs. } \\
90 \pm 33 \times 10^{4} / \mathrm{ml}, 0.4 \pm 0.1 \mathrm{vs} \text {. } \\
1.7 \pm 0.9 \mathrm{mg} / \mathrm{l} \text { ) }\end{array}$ & \\
\hline $\begin{array}{l}\text { Amayasu, } \\
2000 \text { [16] }\end{array}$ & $\begin{array}{l}17 \text { adult } \\
\text { patients } \\
\text { with mild to } \\
\text { moderate } \\
\text { stable asthma }\end{array}$ & $\begin{array}{l}\text { Double-blinded } \\
\text { randomized, crossover } \\
\text { study } \\
\text { Clarithromycin } 200 \mathrm{mg} \\
\text { bid vs. placebo, for } 8 \\
\text { weeks }\end{array}$ & $\begin{array}{l}\text { No improvement in PFTs. } \\
\text { Improvement in symptom score. } \\
\text { Decrease in sputum and blood } \\
\text { eosinophils: sputum } 11 \pm 6 \times 10^{4} / \mathrm{ml} \text { vs. } \\
88 \pm 36 \times 10^{4} / \mathrm{ml} \text {, blood } 12.0 \pm 2.4 \times \\
10^{4} / \mathrm{ml} \text { vs. } 47.5 \pm 6.6 \times 10^{4} / \mathrm{ml} \text {, } \\
\text { clarithromycin vs. placebo, mean } \pm \mathrm{SD} \text {. } \\
\text { Decrease in hyper-reactivity: } \mathrm{Log}\left(\mathrm{PC}_{20^{-}}\right. \\
\text {methacholine) } 2.96 \pm 0.57 \text { vs. } \\
2.60 \pm 0.51 \text {, chlarithromycin vs. placebo }\end{array}$ & \\
\hline $\begin{array}{l}\text { Black, } 2001 \\
\text { [114] }\end{array}$ & $\begin{array}{l}232 \text { adult } \\
\text { patients with } \\
\text { asthma and } \\
\text { IgG/IgA to } C \text {. } \\
\text { pneumoniae }\end{array}$ & $\begin{array}{l}\text { Double-blinded } \\
\text { randomized, placebo- } \\
\text { controlled study. } \\
\text { Roxithromycin } 150 \mathrm{mg} / \\
\text { bid vs. placebo, for } 6 \\
\text { weeks }\end{array}$ & $\begin{array}{l}\text { Improvement in evening PEF (change in } \\
\text { evening PEF, roxithromycin vs. placebo = } \\
15 \mathrm{l} / \mathrm{min} \text { vs. } 3 \mathrm{l} / \mathrm{min}, \mathrm{p}=0.02 \text { ). } \\
\text { No improvement in } \mathrm{FEV}_{1} \text {. } \\
\text { Nonsignificant improvement in symptom } \\
\text { score }\end{array}$ & \\
\hline $\begin{array}{l}\text { Kraft, } 2002 \\
\text { [95] }\end{array}$ & $\begin{array}{l}55 \text { adults } \\
\text { patients with } \\
\text { stable asthma }\end{array}$ & $\begin{array}{l}\text { Double-blinded, } \\
\text { randomized placebo- } \\
\text { controlled study, } \\
\text { clarithromycin } 500 \mathrm{mg} / \\
\text { bid vs. placebo. } \\
\text { The patients were } \\
\text { evaluated by PCR for } \\
\text { infection with Chlamydia } \\
\text { or Mycoplasma }\end{array}$ & $\begin{array}{l}\text { Improvement in } \mathrm{FEV}_{1} \text { found only in PCR- } \\
\text { positive patients in treatment group: } \\
\text { mean } \pm \mathrm{SEM}, 2.50 \pm 0.16 \text { I to } 2.69 \pm \\
0.19 \mathrm{I} \text {. } \\
\text { More decrease in inflammatory } \\
\text { cytokines (TNF- } \alpha, \mathrm{IL}-5, \mathrm{IL}-12 \text { mRNA in } \\
\mathrm{BAL} \text { ) in PCR-positive group }\end{array}$ & $\begin{array}{l}\text { PCR for Chlamydia } \\
\text { or Mycoplasma was } \\
\text { positive in } 31 \text { out of } \\
55 \text { patients }\end{array}$ \\
\hline
\end{tabular}




\begin{tabular}{|c|c|c|c|c|}
\hline $\begin{array}{c}\text { Author, } \\
\text { year [ref.] }\end{array}$ & Patients & $\begin{array}{l}\text { Study design/ } \\
\text { interventions }\end{array}$ & Main outcomes & Note \\
\hline $\begin{array}{l}\text { Kostadima, } \\
2004 \text { [116] }\end{array}$ & $\begin{array}{l}75 \text { adult } \\
\text { patients with } \\
\text { stable asthma } \\
\text { on moderate } \\
\text { dose of inhaled } \\
\text { budesonide }\end{array}$ & $\begin{array}{l}\text { Double-blinded } \\
\text { randomized placebo- } \\
\text { controlled study with } 3 \\
\text { arms. } \\
\text { Clarithromycin } 250 \mathrm{mg} / \\
\text { bid vs. clarithromycin } 250 \\
\mathrm{mg} / \text { tid vs. placebo, for } 8 \\
\text { weeks }\end{array}$ & $\begin{array}{l}\text { No difference in spirometry findings. } \\
\text { Improvement in } \mathrm{PC}_{20} \text {-methacholine } \\
\text { only in clarithromycin treated groups } \\
\text { with trend favouring higher dose group } \\
\text { (before vs. after, median: clarithro bid } \\
0.3 \mathrm{mg} \text { vs } 1.3 \mathrm{mg} \text {, clarithromycin } 250 \\
\mathrm{mg} / \text { tid } 0.4 \mathrm{mg} \text { vs. } 2 \mathrm{mg} \text {, and placebo } 0.4 \\
\mathrm{mg} \text { vs. } 0.3 \mathrm{mg} \text { ) }\end{array}$ & \\
\hline $\begin{array}{l}\text { Strunk, } \\
2008 \text { [120] }\end{array}$ & $\begin{array}{l}55 \text { children } \\
\text { with moderate- } \\
\text { to-severe } \\
\text { asthma who } \\
\text { require inhaled } \\
\text { steroid for } \\
\text { control }\end{array}$ & $\begin{array}{l}\text { Double-blinded } \\
\text { randomized placebo- } \\
\text { controlled study, } 3 \text { arms } \\
\text { azithromycin, } \\
\text { montelukast, or placebo. } \\
\text { Primary outcome was } \\
\text { time to inadequate } \\
\text { control as inhaled steroid } \\
\text { dose was gradually } \\
\text { tapered }\end{array}$ & $\begin{array}{l}\text { No difference were noted for either } \\
\text { treatment compared with placebo } \\
\text { in time to inadequate control status: } \\
\text { azithromycin vs. montelukast vs. placebo } \\
=8.4 \text { wks }(95 \% \mathrm{Cl} 4.3-17.3) \text { vs. } 13.9 \\
\text { wks }(95 \% \mathrm{Cl} 4.7-20.6) \text { vs. } 19.1 \text { wks } \\
\text { ( } 95 \% \mathrm{Cl}=11.7 \text {-infinity) }\end{array}$ & $\begin{array}{l}\text { The study was } \\
\text { prematurely } \\
\text { terminated due to } \\
\text { futility }\end{array}$ \\
\hline $\begin{array}{l}\text { Simpson, } \\
2008 \text { [17] }\end{array}$ & $\begin{array}{l}45 \text { adult } \\
\text { patients } \\
\text { with severe } \\
\text { refractory } \\
\text { asthma }\end{array}$ & $\begin{array}{l}\text { Double-blinded, } \\
\text { randomized placebo- } \\
\text { controlled study. } \\
\text { Clarithromycin } 500 \mathrm{mg} \\
\text { bid vs placebo, for } 8 \\
\text { weeks }\end{array}$ & $\begin{array}{l}\text { Decrease in IL-8: clarithro vs. placebo, } \\
3.9((\mathrm{IQR}=1.8-5.4) \text { vs. } 6.4(\mathrm{IQR}=3.7- \\
11.3), \mathrm{p}<0.05 \\
\text { Decrease in } \mathrm{MMP}-9(\mathrm{ng} / \mathrm{ml}) \text { : clarithro } \\
\text { vs. placebo, } 3074(\mathrm{IQR}=1,806-7,084) \\
\text { vs. } 6724(\mathrm{IQR}=3620-14,335), \mathrm{p}< \\
0.05 . \\
\text { No difference in FEV } \text { and symptoms } \\
\text { score. } \\
\text { No significant improvement in sputum } \\
\text { neutrophil counts and neutrophil } \\
\text { elastase level. } \\
\text { These trends are more pronounced in } \\
\text { noneosinophilic asthma patients }\end{array}$ & \\
\hline $\begin{array}{l}\text { Sutherland, } \\
2010 \text { [119] }\end{array}$ & $\begin{array}{l}92 \text { adult } \\
\text { patients } \\
\text { with mild- } \\
\text { to-moderate } \\
\text { asthma that } \\
\text { was not well } \\
\text { controlled }\end{array}$ & $\begin{array}{l}\text { Double-blinded } \\
\text { randomized placebo- } \\
\text { controlled study. Stratified } \\
\text { according to PCR result } \\
\text { for } M \text {. pneumoniae or C. } \\
\text { pneumoniae. } \\
\text { Clarithromycin } 500 \mathrm{mg} / \\
\text { bid vs. placebo, for } 16 \\
\text { weeks }\end{array}$ & $\begin{array}{l}\text { No difference in } A C Q \text { score. } \\
\text { No difference in PFTs. } \\
\text { No difference in exhaled nitric oxide } \\
\text { Improvement in bronchial hyper- } \\
\text { responsiveness measured in } \mathrm{PC}_{20}{ }^{-} \\
\text {methacholine: mean } \pm \mathrm{SE}, 1.2 \pm 0.5 \\
\text { doubling doses }(p=0.02)\end{array}$ & $\begin{array}{l}\text { Originally } \\
\text { planned to recruit } \\
\text { approximately } 75 \\
\text { patients in each } \\
\text { arm. However, the } \\
\text { recruitment for PCR- } \\
\text { positive patients } \\
\text { did not reach the } \\
\text { goal due to lower- } \\
\text { than-expected PCR } \\
\text { positivity. Only } 12 \\
\text { out of } 92 \text { patients } \\
\text { were PCR positive }\end{array}$ \\
\hline
\end{tabular}

Table II. Summary of clinical trials: double-blinded randomized controlled trials whose treatment duration is at least 4 weeks with clinical outcomes

$95 \% \mathrm{Cl}=95 \%$ confidence interval; $\mathrm{ACQ}=$ asthma control questionnaire; $\mathrm{BAL}=$ bronchoalveolar lavage;

$\mathrm{ECP}=$ eosinophil cationic protein; $\mathrm{FEV}_{1}=$ forced expiratory volume at 1 second; $\mathrm{IQR}=$ interquartile range;

$\mathrm{PC}_{20}$-methacholine = provocative concentration of methacholine causing a $20 \%$ fall in $\mathrm{FEV}_{1}$;

$\mathrm{PEF}=$ peak expiratory flow; $\mathrm{PFT}=$ pulmonary function test; $\mathrm{SD}=$ standard deviation; $\mathrm{SE}=$ standard error 
The most recently published Cochrane systematic review on macrolides for chronic asthma summarised all relevant randomized controlled trials (RCTs) up to May 2007 [124]. This review identified 7 RCTs in which asthma was treated with a macrolide for at least 4 weeks. A total of 416 patients were recruited. The meta-analysis demonstrated no significant difference in $\mathrm{FEV}_{1}$, despite significant differences noted in markers of eosiniphilic inflammation and symptoms. The authors concluded that «these data are insufficient to recommend the routine use of macrolides for control of asthma at present, even though some clinical data indicate a positive effect». They pointed out that the quality of these studies was generally low and that the patient samples were heterogeneous. They concluded that larger well designed studies are needed.

Since the Cochrane review, there have been 3 RCTs. One involved children and the others included adult patients. These three new RCTs are also not encouraging.

Strunk et al. included 55 children 6 to 17 years of age with moderate-to-severe persistent asthma [66]. They were randomized to 3 groups: 1. placebo, 2. azithromycin (250 mg for those $25-40 \mathrm{~kg}$ or $500 \mathrm{mg}$ for those $>40 \mathrm{~kg}$ once daily), and 3. montelukast $5 \mathrm{mg}$ or $10 \mathrm{mg}$ once daily (based on age). The primary outcome was time from randomization to inadequate asthma control. The protocol included a sequential budesonide dose reduction after 6 weeks of treatment with investigation medications. The study was originally designed to recruit 210 randomized children. However, the study was terminated after randomized 55 patients due to futility (median time to inadequate control status: azithromycin median 8.4 weeks $(95 \% \mathrm{CI}=4.3-17.3)$, montelukast 13.9 weeks $(95 \% \mathrm{CI}=4.7-20.6)$, placebo 19.1 weeks $(95 \% \mathrm{CI}=11.7$-infinity). Of note, the well accepted treatment with montelukast also did not show benefit in this study.

Simpson et al. randomized 46 adult patients with symptomatic refractory asthma to chlarithromycin $500 \mathrm{mg} / \mathrm{bid}$ vs. placebo for 8 weeks [17]. The randomization was stratified according to high and low neutrophil counts in the sputum. The treatment group demonstrated significant reduction in airway IL-8 levels and MMP-9 levels compared with placebo (IL-8, ng/ml: 3.9 (IQR = 1.8-5.4) vs. 6.4 (IQR = 3.7-11.3); MMP-9, ng/ml: $3074(\mathrm{IQR}=1,806-7,084)$ vs. $6724(\mathrm{IQR}=3620-14,335)$ ). There was also a trend towards decreased sputum neutrophil counts and improvement in asthma control scores in the treatment group; however, these values were not statistically significant when compared to placebo. There was also no improvement in spirometric findings. Of the 46 patients, 28 patients had noneosinophilic asthma and the above mentioned findings were more pronounced in this subgroup.

Sutherland et al. recruited 92 adult asthma patients with mild-to-moderate persistent asthma that was not well controlled despite treatment with low-dose inhaled corticosteroids [119]. The patients were divided based on the result of lower airway PCR for M. pneumoniae or C. pneumoniae (there were 80 patients in PCR negative group and 12 in positive group). Within each group, patients were randomized to either clarithromycn $(500 \mathrm{mg} / \mathrm{bid})$ or placebo. The primary outcome was the change in the Asthma Control Questionnaire (ACQ) score after 16 weeks of study treatment. Although underpowered, no beneficial effect of clarithromycin was noted in the ACQ score in either patient group or overall. The authors also observed no difference in pulmonary function tests, in exhaled nitric oxide concentration, or in Asthma Quality of Life Questionnaire Score which were secondary outcomes. There was a small improvement in $\mathrm{PC}_{20}$ doubling dose $(1.2 \pm 0.5, \mathrm{p}=0.01)$.

\section{Potential adverse effects}

A well written summary article by Altenburg et al. finds that gastrointestinal complaints are the most common adverse effects of macrolide therapy [1]. Other infrequently reported side effects are rash and hepatotoxicity. Rare but well known and potentially significant adverse reactions include ototoxicity and cardiac toxicity. Development of antibiotic resistance is also a concern. Given that the benefit of chronic macrolide use for asthma is still uncertain, clinicians should use careful judgment in case-by-case bases. 


\section{Conclusion and future directions}

Asthma has been recognized as a heterogeneous disease [6]. Corticosteroids have been a mainstay of asthma treatment for years. However, it is well recognized that there are subgroups of patients who are resistant or not well controlled with corticosteroids and there is a strong need for other effective therapies. Recently, newer agents that are more focused on specific pathologic processes are increasingly available. Anti-IgE monoclonal antibody (omalizumab), anti-IL5 monoclonal antibody (mepolizumab), anti-TNF- $\alpha$ agents (such as infliximab, etanercept, adalimumab, golimumab), and anti-leukotriene agents (such as montelukast, zileuton) are some examples. Even though these agents may not be as effective as corticosteroids in the general asthma population, they can be very effective in certain subgroups of asthma patients. Macrolides have been recognised for their immunomodulatory effects and have attracted great interest as an additional asthma treatment. However, clinical trials conducted on general asthma populations have been conflicting. It may be that there are not enough well designed RCTs, but it may also be the case that macrolides are only effective in certain subgroups of asthma patients. Macrolides exert their immunomodulatory effects through a wide range of mechanisms as discussed above. However, suppression of neutrophilic inflammation through inhibition of NF-kB and AP-1 pathways seems to be a major mechanism [78,125-132]. Hence, the most promising asthma subpopulations in which macrolides may be most effective are patients with noneosinophilic asthma and patients with chronic airway infection. Additional well designed clinical trials are needed to answer this question. Until then, macrolides will remain as a potentially attractive but not yet proven treatment option of asthma.

Questions for further research

It is important to identify subgroup of asthma patients who benefit from macrolide antibiotics. Asthmatics with evidence of chronic atypical infection or patients with noneosinophilic asthma are the most promising.

\section{The review in brief}

\begin{tabular}{|c|c|}
\hline Clinical question & Overview of the current knowledge on macrolide antibiotics in asthma therapy \\
\hline Type of review & Narrative \\
\hline Search of the literature & $\begin{array}{l}\text { PubMed, with keywords: Macrolide; Asthma; Chronic inflammation; Immunomodulation; } \\
\text { Noneosinophilic asthma }\end{array}$ \\
\hline Conclusions & $\begin{array}{l}\text { Macrolides have immunomodulatory property, which acts on various aspect of immune } \\
\text { system. Despite anecdotal success, they lack definitive evidence in asthma therapy. Results of } \\
\text { randomized controlled trials are conflicting. Further studies are necessary, which are focused on } \\
\text { particular subgroups of asthma patients. }\end{array}$ \\
\hline Limitations & Clinical trials on specific subgroup of asthma are limited. \\
\hline
\end{tabular}

\section{References}

1. Altenburg J, de Graaff CS, van der Werf TS, Boersma WG. Immunomodulatory effects of macrolide antibiotics - part 2: advantages and disadvantages of long-term, low-dose macrolide therapy. Respiration 2011; 81: 75-87

2. Crosbie PA, Woodhead MA. Long-term macrolide therapy in chronic inflammatory airway diseases. Eur Respir J 2009; 33: 171-81 
3. Kudoh S, Azuma A, Yamamoto M, Izumi T, Ando M. Improvement of survival in patients with diffuse panbronchiolitis treated with low-dose erythromycin. Am J Respir Crit Care Med 1998; 157: 1829-32

4. Kudoh S, Uetake T, Hagiwara K, Hirayama M, Hus LH, Kimura H, et al. Clinical effects of lowdose long-term erythromycin chemotherapy on diffuse panbronchiolitis. Nihon Kyobu Shikkan Gakkai Zasshi 1987; 25: 632-42

5. Busse WW, Lemanske RF Jr. Asthma. N Engl J Med 2001; 344: 350-62

6. Green $\mathrm{RH}$, Brightling $\mathrm{CE}$, Bradding P. The reclassification of asthma based on subphenotypes. Curr Opin Allergy Clin Immunol 2007; 7: 43-50

7. Douwes J, Gibson P, Pekkanen J, Pearce N. Non-eosinophilic asthma: importance and possible mechanisms. Thorax 2002; 57: 643-8

8. Fahy JV. Eosinophilic and neutrophilic inflammation in asthma: insights from clinical studies. Proc Am Thorac Soc 2009; 6: 256-9

9. Hatipoglu U, Rubinstein I. Low-dose, long-term macrolide therapy in asthma: An overview. Clin Mol Allergy 2004; 2: 4

10. Lugogo N, Que LG. Ch38: Asthma. In: Mason RJ, Broaddus VC, Martin TR, King, TE, Schraufnagel DE, Murray JF, et al (eds). Textbook of respiratory medicine, $5^{\text {th }}$ edition. Philadelphia: Saunders 2010

11. Barnes PJ. The cytokine network in asthma and chronic obstructive pulmonary disease. J Clin Invest 2008; 118: 3546-56

12. He XY, Simpson JL, Wang F. Inflammatory phenotypes in stable and acute childhood asthma. Paediatr Respir Rev 2011; 12: 165-9

13. Noma T, Aoki K, Hayashi M, Yoshizawa I, Kawano Y. Effect of roxithromycin on T lymphocyte proliferation and cytokine production elicited by mite antigen. Immunopharmacol 2001; 1: 201-10

14. Lin SJ, Lee WJ, Liang YW, Yan DC, Cheng PJ, Kuo ML. Azithromycin Inhibits IL-5 Production of T Helper Type 2 Cells from Asthmatic Children. Int Arch Allergy Immunol 2011; 156: 179-86

15. Beigelman A, Gunsten S, Mikols CL, Vidavsky I, Cannon CL, Brody SL, et al. Azithromycin attenuates airway inflammation in a noninfectious mouse model of allergic asthma. Chest 2009; 136: 498-506

16. Amayasu H, Yoshida S, Ebana S, Yamamoto Y, Nishikawa T, Shoji T, et al. Clarithromycin suppresses bronchial hyperresponsiveness associated with eosinophilic inflammation in patients with asthma. Ann Allergy Asthma Immunol 2000; 84: 594-8

17. Simpson JL, Powell H, Boyle MJ, Scott RJ, Gibson PG. Clarithromycin targets neutrophilic airway inflammation in refractory asthma. Am J Respir Crit Care Med 2008; 177: 148-55

18. Mori A, Kaminuma O, Ogawa K, Nakata A, Egan RW, Akiyama K, et al. Control of IL-5 production by human helper $\mathrm{T}$ cells as a treatment for eosinophilic inflammation: comparison of in vitro and in vivo effects between selective and nonselective cytokine synthesis inhibitors. J Allergy Clin Immunol 2000; 106: S58-S64

19. Konno S, Adachi M, Asano K, Okamoto K, Takahashi T. Anti-allergic activity of roxithromycin: inhibition of interleukin-5 production from mouse T lymphocytes. Life Sci 1993; 52: PL25-PL30

20. Tanabe T, Kanoh S, Tsushima K, Yamazaki Y, Kubo K, Rubin BK. Clarithromycin Inhibits Interleukin-13-Induced Goblet Cell Hyperplasia in Human Airway Cells. Am J Respir Cell Mol Biol 2011 Jun 3. [Epub ahead of print], PMID: 21642590

21. Konno S, Asano K, Kurokawa M, Ikeda K, Okamoto K, Adachi M. Antiasthmatic activity of a macrolide antibiotic, roxithromycin: analysis of possible mechanisms in vitro and in vivo. Int Arch Allergy Immunol 1994; 105: 308-16

22. Sato E, Nelson DK, Koyama S, Hoyt JC, Robbins RA. Erythromycin modulates eosinophil chemotactic cytokine production by human lung fibroblasts in vitro. Antimicrob Agents Chemother 2001; 45: 401-6 
23. Murphy DM, Forrest IA, Corris PA, Johnson GE, Small T, Jones D, et al. Azithromycin attenuates effects of lipopolysaccharide on lung allograft bronchial epithelial cells. J Heart Lung Transplant 2008; 27: 1210-6

24. Zimmermann GS, Neurohr C, Villena-Hermoza H, Hatz R, Behr J. Anti-inflammatory effects of antibacterials on human Bronchial epithelial cells. Respir Res 2009; 10: 89

25. Vanaudenaerde BM, Wuyts WA, Geudens N, Dupont LJ, Schoofs K, Smeets S, et al. Macrolides inhibit IL17-induced IL8 and 8-isoprostane release from human airway smooth muscle cells. Am J Transplant 2007; 7: 76-82

26. Takizawa H, Desaki M, Ohtoshi T, Kawasaki S, Kohyama T, Sato M, et al. Erythromycin modulates IL-8 expression in normal and inflamed human bronchial epithelial cells. Am J Respir Crit Care Med 1997; 156: 266-71

27. Kurdowska A, Noble JM, Griffith DE. The effect of azithromycin and clarithromycin on ex vivo interleukin-8 (IL-8) release from whole blood and IL-8 production by human alveolar macrophages. J Antimicrob Chemother 2001; 47: 867-70

28. Kohyama T, Takizawa H, Kawasaki S, Akiyama N, Sato M, Ito K. Fourteen-member macrolides inhibit interleukin-8 release by human eosinophils from atopic donors. Antimicrob Agents Chemother 1999; 43: 907-11

29. Oishi K, Sonoda F, Kobayashi S, Iwagaki A, Nagatake T, Matsushima K, et al. Role of interleukin-8 (IL-8) and an inhibitory effect of erythromycin on IL-8 release in the airways of patients with chronic airway diseases. Infect Immun 1994; 62: 4145-52

30. Nakajima T, Yoshizawa I, Kawano Y, Noma T. Suppressive effect of roxithromycin on the induction of IL-2 responsiveness by DF-stimulated lymphocytes from patients with bronchial asthma. Arerugi 1996; 45: 554-61

31. Karakawa M, Komine M, Tamaki K, Ohtsuki M. Roxithromycin downregulates production of CTACK/CCL27 and MIP-3a/CCL20 from epidermal keratinocytes. Arch Dermatol Res 2010; 302: 763-7

32. Yamauchi K, Shibata Y, Kimura T, Abe S, Inoue S, Osaka D, et al. Azithromycin suppresses interleukin-12p40 expression in lipopolysaccharide and interferon-gamma stimulated macrophages. Int J Biol Sci 2009; 5: 667-78

33. Takizawa H, Desaki M, Ohtoshi T, Kikutani T, Okazaki H, Sato M, et al. Erythromycin suppresses interleukin 6 expression by human bronchial epithelial cells: a potential mechanism of its antiinflammatory action. Biochem Biophys Res Commun 1995; 210: 781-6

34. Sato Y, Kaneko K, Inoue M. Macrolide antibiotics promote the LPS-induced upregulation of prostaglandin E receptor EP2 and thus attenuate macrolide suppression of IL-6 production. Prostaglandins Leukot Essent Fatty Acids 2007; 76: 181-8

35. Leiva M, Ruiz-Bravo A, Jimenez-Valera M. Effects of telithromycin in in vitro and in vivo models of lipopolysaccharide-induced airway inflammation. Chest 2008; 134: 20-9

36. Aghai ZH, Kode A, Saslow JG, Nakhla T, Farhath S, Stahl GE, et al. Azithromycin suppresses activation of nuclear factor-kappa $B$ and synthesis of pro-inflammatory cytokines in tracheal aspirate cells from premature infants. Pediatr Res 2007; 62: 483-8

37. Cigana C, Assael BM, Melotti P. Azithromycin selectively reduces tumor necrosis factor alpha levels in cystic fibrosis airway epithelial cells. Antimicrob Agents Chemother 2007; 51: 975-81

38. Suzaki H, Asano K, Ohki S, Kanai K, Mizutani T, Hisamitsu T. Suppressive activity of a macrolide antibiotic, roxithromycin, on pro-inflammatory cytokine production in vitro and in vivo. Mediators Inflamm 1999; 8: 199-204

39. Khair OA, Devalia JL, Abdelaziz MM, Sapsford RJ, Davies RJ. Effect of erythromycin on Haemophilus influenzae endotoxin-induced release of IL-6, IL- 8 and sICAM-1 by cultured human bronchial epithelial cells. Eur Respir J 1995; 8: 1451-7 
40. Takizawa H, Desaki M, Ohtoshi T, Kawasaki S, Kohyama T, Sato M, et al. Erythromycin and clarithromycin attenuate cytokine-induced endothelin-1 expression in human bronchial epithelial cells. Eur Respir J 1998; 12: 57-63

41. Ci X, Chu X, Xiang H, Li X, Deng X. Anti-inflammatory effects of tilmicosin in a noninfectious mouse model of allergic asthma. Immunopharmacol Immunotoxicol. 2011 Mar 23. [Epub ahead of print], PMID: 21428709

42. Eigelman A, Gunsten S, Mikols CL, Vidavsky I, Cannon CL, Brody SL, et al. Azithromycin attenuates airway inflammation in a noninfectious mouse model of allergic asthma. Chest 2009; 136: 498-506

43. Hersperger R, Buchheit KH, Cammisuli S, Enz A, Lohse O, Ponelle M, et al. A locally active antiinflammatory macrolide (MLD987) for inhalation therapy of asthma. J Med Chem 2004; 47: 4950-7

44. Urasaki Y, Nori M, Iwata S, Sasaki T, Hosono O, Kawasaki H, et al. Roxithromycin specifically inhibits development of collagen induced arthritis and production of proinflammatory cytokines by human T cells and macrophages. Rheumatol 2005; 32: 1765-74

45. Sugiyama Y, Yanagisawa K, Tominaga SI, Kitamura S. Effects of long-term administration of erythromycin on cytokine production in rat alveolar macrophages. Eur Respir J 1999; 14: 1113-6

46. Bosnar M, Bosnjak B, Cuzic S, Hrvacic B, Marjanovic N, Glojnaric I, et al. Azithromycin and clarithromycin inhibit lipopolysaccharide-induced murine pulmonary neutrophilia mainly through effects on macrophage-derived granulocyte-macrophage colony-stimulating factor and interleukin-1beta. J Pharmacol Exp Ther 2009; 331: 104-13

47. Meyer M, Huaux F, Gavilanes X, van den Brûle S, Lebecque P, Lo Re S, et al. Azithromycin reduces exaggerated cytokine production by M1 alveolar macrophages in cystic fibrosis. Am J Respir Cell Mol Biol 2009; 41: 590-602

48. Wuyts WA, Willems S, Vos R, Vanaudenaerde BM, De Vleeschauwer SI, Rinaldi M, et al. Azithromycin reduces pulmonary fibrosis in a bleomycin mouse model. Exp Lung Res 2010; 36: 602-14

49. Remund K, Rechsteiner T, Guo Z, Rentsch K, Boehler A. The macrolide clarithromycin inhibits experimental post-transplant bronchiolitis obliterans. Exp Lung Res 2009; 35: 830-40

50. Tsai WC, Hershenson MB, Zhou Y, Sajjan U. Azithromycin increases survival and reduces lung inflammation in cystic fibrosis mice. Inflamm Res 2009; 58: 491-501

51. Geudens N, Timmermans L, Vanhooren H, Vanaudenaerde BM, Vos R, Van De Wauwer C, et al. Azithromycin reduces airway inflammation in a murine model of lung ischaemia reperfusion injury. Transpl Int 2008; 21: 688-95

52. Ivetić Tkalcević V, Bosnjak B, Hrvacić B, Bosnar M, Marjanović N, Ferencić Z, et al. Anti-inflammatory activity of azithromycin attenuates the effects of lipopolysaccharide administration in mice. Eur J Pharmacol 2006; 539: 131-8

53. Li YJ, Azuma A, Usuki J, Abe S, Matsuda K, Sunazuka T, et al. EM703 improves bleomycin-induced pulmonary fibrosis in mice by the inhibition of TGF-beta signaling in lung fibroblasts. Respir Res 2006; 7: 16

54. Tsai WC, Rodriguez ML, Young KS, Deng JC, Thannickal VJ, Tateda K, et al. Azithromycin blocks neutrophil recruitment in Pseudomonas endobronchial infection. Am J Respir Crit Care Med 2004; 170: $1331-9$

55. Takahashi T, Suga M, Matsukawa A, Sato K, Okamoto T, Ichiyasu H, et al. Erythromycin attenuates an experimental model of chronic bronchiolitis via augmenting monocyte chemoattractant protein-1. Eur Respir J 2001; 17: 360-7

56. Suzaki H, Asano K, Ohki S, Kanai K, Mizutani T, Hisamitsu T. Suppressive activity of a macrolide antibiotic, roxithromycin, on pro-inflammatory cytokine production in vitro and in vivo. Mediators Inflamm 1999; 8: 199-204

57. Tamaoki J, Kondo M, Kohri K, Aoshiba K, Tagaya E, Nagai A. Macrolide antibiotics protect against immune complex-induced lung injury in rats: role of nitric oxide from alveolar macrophages. $J$ Immunol 1999; 163: 2909-15 
58. Miyajima M, Suga M, Nakagawa K, Ito K, Ando M. Effects of erythromycin on experimental extrinsic allergic alveolitis. Clin Exp Allergy 1999; 29: 253-61

59. Duong M, Simard M, Bergeron Y, Ouellet N, Côté-Richer M, Bergeron MG. Immunomodulating effects of HMR 3004 on pulmonary inflammation caused by heat-killed Streptococcus pneumoniae in mice. Antimicrob Agents Chemother 1998; 42: 3309-12

60. Chen B, Jiang L, Zhao W, Yu R, Hou XM. Ameliorating effect of erythromycin on bleomycin-induced pulmonary fibrosis: role of alveolar macrophage activation and cytokine release. Respirology 1997; 2: 151-5

61. Konno S, Asano K, Kurokawa M, Ikeda K, Okamoto K, Adachi M. Antiasthmatic activity of a macrolide antibiotic, roxithromycin: analysis of possible mechanisms in vitro and in vivo. Int Arch Allergy Immunol 1994; 105: 308-16

62. Konno S, Asano K, Kurokawa M, Ikeda K, Okamoto K, Adachi M. Antiasthmatic activity of a macrolide antibiotic, roxithromycin: analysis of possible mechanisms in vitro and in vivo. Int Arch Allergy Immunol 1994; 105: 308-16

63. Korematsu S, Yamamoto K, Nagakura T, Miyahara H, Okazaki N, Akiyoshi K, et al. The indication and effectiveness of low-dose erythromycin therapy in pediatric patients with bronchial asthma. Pediatr Allergy Immunol 2010; 21: 489-92

64. Fonseca-Aten M, Okada PJ, Bowlware KL, Chavez-Bueno S, Mejias A, Rios AM, et al. Effect of clarithromycin on cytokines and chemokines in children with an acute exacerbation of recurrent wheezing: a double-blind, randomized, placebo-controlled trial. Ann Allergy Asthma Immunol 2006; 97: 457-63

65. Federica M, Nadia S, Monica M, Alessandro C, Tiberio O, Francesco B, et al. Clinical and immunological evaluation of 12 -month azithromycin therapy in chronic lung allograft rejection. Clin Transplant 2011 [Epub ahead of print], PMID: 21418327

66. Verleden GM, Vanaudenaerde BM, Dupont LJ, Van Raemdonck DE. Azithromycin reduces airway neutrophilia and interleukin-8 in patients with bronchiolitis obliterans syndrome. Am J Respir Crit Care Med 2006; 174: 566-70

67. Pukhalsky AL, Shmarina GV, Kapranov NI, Kokarovtseva SN, Pukhalskaya D, Kashirskaja NJ. Anti-inflammatory and immunomodulating effects of clarithromycin in patients with cystic fibrosis lung disease. Mediators Inflamm 2004; 13: 111-7

68. Banerjee D, Honeybourne D, Khair OA. The effect of oral clarithromycin on bronchial airway inflammation in moderate-to-severe stable COPD: a randomized controlled trial. Treat Respir Med 2004; 3: 59-65

69. Demartini G, Esposti D, Marthyn P, Lapidari A, Fraschini F, Scaglione F. Effect of multiple doses of clarithromycin and amoxicillin on IL-6, IFNgamma and IL-10 plasma levels in patients with community acquired pneumonia. J Chemother 2004; 16: 82-5

70. Criqui GI, Solomon C, Welch BS, Ferrando RE, Boushey HA, Balmes JR. Effects of azithromycin on ozone-induced airway neutrophilia and cytokine release. Eur Respir J 2000; 15: 856-62

71. Oishi K, Sonoda F, Kobayashi S, Iwagaki A, Nagatake T, Matsushima K, et al. Role of interleukin-8 (IL-8) and an inhibitory effect of erythromycin on IL-8 release in the airways of patients with chronic airway diseases. Infect Immun 1994; 62: 4145-52

72. Simpson JL, Phipps S, Gibson PG. Inflammatory mechanisms and treatment of obstructive airway diseases with neutrophilic bronchitis. Pharmacol Ther 2009; 124: 86-95

73. Krysko O, Vandenabeele P, Krysko DV, Bachert C. Impairment of phagocytosis of apoptotic cells and its role in chronic airway diseases. Apoptosis 2010; 15: 1137-46

74. Inamura K, Ohta N, Fukase S, Kasajima N, Aoyagi M. The effects of erythromycin on human peripheral neutrophil apoptosis. Rhinology 2000; 38: 124-9

75. Aoshiba K, Nagai A, Konno K. Erythromycin shortens neutrophil survival by accelerating apoptosis. Antimicrob Agents Chemother 1995; 39: 872-7 
76. Koch CC, Esteban DJ, Chin AC, Olson ME, Read RR, Ceri H, et al. Apoptosis, oxidative metabolism and interleukin-8 production in human neutrophils exposed to azithromycin: effects of Streptococcus pneumoniae. J Antimicrob Chemother 2000; 46: 19-26

77. Lin SJ, Lee WJ, Liang YW, Yan DC, Cheng PJ, Kuo ML. Azithromycin Inhibits IL-5 Production of T Helper Type 2 Cells from Asthmatic Children. Int Arch Allergy Immunol 2011; 156: 179-86

78. Ogawa N, Sugawara Y, Fujiwara Y, Noma T. Roxithromycin promotes lymphocyte apoptosis in Dermatophagoides-sensitive asthma patients. Eur J Pharmacol 2003; 474: 273-81

79. Noma T, Ogawa N. Roxithromycin enhances lymphocyte apoptosis in Dermatophagoides-sensitive childhood asthma. J Allergy Clin Immunol 2003; 111: 646-7

80. Adachi T, Motojima S, Hirata A, Fukuda T, Kihara N, Kosaku A, et al. Eosinophil apoptosis caused by theophylline, glucocorticoids, and macrolides after stimulation with IL-5. J Allergy Clin Immunol 1996; 98: S207-S215

81. Borszcz PD, Befus D, Moqbel R, Sin DD, Adamko DJ, Man SF, et al. Effects of clarithromycin on inflammatory cell mediator release and survival. Chemotherapy 2005; 51: 206-10

82. Stamatiou R, Boukas K, Paraskeva E, Molyvdas PA, Hatziefthimiou A. Azithromycin reduces the viability of human bronchial smooth muscle cells. J Antibiot (Tokyo) 2010; 63: 71-5

83. Huynh ML, Malcolm KC, Kotaru C, Tilstra JA, Westcott JY, Fadok VA, et al. Defective apoptotic cell phagocytosis attenuates prostaglandin E2 and 15-hydroxyeicosatetraenoic acid in severe asthma alveolar macrophages. Am J Respir Crit Care Med 2005; 172: 972-9

84. Yamaryo T, Oishi K, Yoshimine H, Tsuchihashi Y, Matsushima K, Nagatake T. Fourteen-member macrolides promote the phosphatidylserine receptor-dependent phagocytosis of apoptotic neutrophils by alveolar macrophages. Antimicrob Agents Chemother 2003; 47: 48-53

85. Hodge S, Hodge G, Brozyna S, Jersmann H, Holmes M, Reynolds PN. Azithromycin increases phagocytosis of apoptotic bronchial epithelial cells by alveolar macrophages. Eur Respir J 2006; 28: 486-95

86. Lai HY, Rogers DF. Mucus hypersecretion in asthma: intracellular signalling pathways as targets for pharmacotherapy. Curr Opin Allergy Clin Immunol 2010; 10: 67-76

87. Ou XM, Feng YL, Wen FQ, Wang K, Yang J, Deng ZP, et al. Macrolides attenuate mucus hypersecretion in rat airways through inactivation of NF-kappaB. Respirology 2008; 13: 63-72

88. Shimizu T, Shimizu S, Hattori R, Gabazza EC, Majima Y. In vivo and in vitro effects of macrolide antibiotics on mucus secretion in airway epithelial cells. Am J Respir Crit Care Med 2003; 168: 581-7

89. Tamaoki J, Kadota J, Takizawa H. Clinical implications of the immunomodulatory effects of macrolides. Am J Med 2004; 117 (Suppl 9A): 5S-11S

90. Tamaoki J, Takeyama K, Tagaya E, Konno K. Effect of clarithromycin on sputum production and its rheological properties in chronic respiratory tract infections. Antimicrob Agents Chemother 1995; 39: 1688-90

91. Tagaya E, Tamaoki J, Kondo M, Nagai A. Effect of a short course of clarithromycin therapy on sputum production in patients with chronic airway hypersecretion. Chest 2002; 122: 213-8

92. Rubin BK, Druce H, Ramirez OE, Palmer R. Effect of clarithromycin on nasal mucus properties in healthy subjects and in patients with purulent rhinitis. Am J Respir Crit Care Med 1997; 155: 2018-23

93. Martin RJ, Kraft M, Chu HW, Berns EA, Cassell GH. A link between chronic asthma and chronic infection. J Allergy Clin Immunol 2001; 107: 595-601

94. Kocabas A, Avsar M, Hanta I, Koksal F, Kuleci S. Chlamydophila pneumoniae infection in adult asthmatics patients. J Asthma 2008; 45: 39-43

95. Kraft M, Cassell GH, Pak J, Martin RJ. Mycoplasma pneumoniae and Chlamydia pneumoniae in asthma: effect of clarithromycin. Chest 2002; 121: 1782-8 
96. Johnston SL. Macrolide antibiotics and asthma treatment. Allergy Clin Immunol 2006; 117: 1233-6

97. Sato K, Suga M, Akaike T, Fujii S, Muranaka H, Doi T, et al. Therapeutic effect of erythromycin on influenza virus-induced lung injury in mice. Am J Respir Crit Care Med 1998; 157: 853-7

98. Beigelman A, Mikols CL, Gunsten SP, Cannon CL, Brody SL, Walter MJ. Azithromycin attenuates airway inflammation in a mouse model of viral bronchiolitis. Respir Res 2010; 11: 90

99. Amsden GW. Anti-inflammatory effects of macrolides--an underappreciated benefit in the treatment of community-acquired respiratory tract infections and chronic inflammatory pulmonary conditions? Antimicrob Chemother 2005; 55: 10-21

100. Tsurita M, Kurokawa M, Imakita M, Fukuda Y, Watanabe Y, Shiraki K. Early augmentation of interleukin (IL)-12 level in the airway of mice administered orally with clarithromycin or intranasally with IL-12 results in alleviation of influenza infection. J Pharmacol Exp Ther 2001; 298: 362-8

101. Tahan F, Ozcan A, Koc N. Clarithromycin in the treatment of RSV bronchiolitis: a double-blind, randomised, placebo-controlled trial. Eur Respir J 2007; 29: 91-7

102. Ninomiya K. Beneficial effects of macrolide antibiotics on children with influenza. Jpn J Antibiot 2003; 56(Suppl A): 84-6

103. Bermejo-Martin JF, Kelvin DJ, Eiros JM, Castrodeza J, Ortiz de Lejarazu R. Macrolides for the treatment of severe respiratory illness caused by novel H1N1 swine influenza viral strains. J Infect Dev Ctries 2009; 3: 159-61

104. Johnston SL, Blasi F, Black PN, Martin RJ, Farrell DJ, Nieman RB; TELICAST Investigators. The effect of telithromycin in acute exacerbations of asthma. N Engl J Med 2006; 354: 1589-600

105. Dozor AJ. The role of oxidative stress in the pathogenesis and treatment of asthma. Ann N Y Acad Sci 2010; 1203: 133-7

106. Comhair SA, Erzurum SC. Redox control of asthma: molecular mechanisms and therapeutic opportunities. Antioxid Redox Signal 2010; 12: 93-124

107. Kamoi H, Kurihara N, Fujiwara H, Hirata K, Takeda T. The macrolide antibacterial roxithromycin reduces bronchial hyperresponsiveness and superoxide anion production by polymorphonuclear leukocytes in patients with asthma. J Asthma 1995; 32: 191-7

108. Cui CH, Honda K, Saito N, Yamada Y, Sannohe S, Ueki S, et al. Effect of roxithromycin on eotaxinprimed reactive oxygen species from eosinophils. Int Arch Allergy Immunol 2001; 125(Suppl 1): 38-41

109. Mitsuyama T, Furuno T, Hidaka K, Tanaka T, Abe M, Hara N. Inhibition by erythromycin of human pulmonary artery endothelial cell injury induced by human neutrophils. Respiration 1997; 64: 206-10

110. Kadir T, Izzetin FV, Cevikbaş A, Johansson CB, Clark P. In vitro effects of clarithromycin on human polymorphonuclear leukocyte functions. Chemotherapy 2000; 46: 198-203

111. Kohri K, Tamaoki J, Kondo M, Aoshiba K, Tagaya E, Nagai A. Macrolide antibiotics inhibit nitric oxide generation by rat pulmonary alveolar macrophages. Eur Respir J 2000; 15: 62-7

112. Terao H, Asano K, Kanai K, Kyo Y, Watanabe S, Hisamitsu T, et al. Suppressive activity of macrolide antibiotics on nitric oxide production by lipopolysaccharide stimulation in mice. Mediators Inflamm 2003; 12: 195-202

113. Borszcz PD, Befus D, Moqbel R, Sin DD, Adamko DJ, Man SF, et al. Effects of clarithromycin on inflammatory cell mediator release and survival. Chemotherapy 2005; 51: 206-10

114. Black PN, Blasi F, Jenkins CR, Scicchitano R, Mills GD, Rubinfeld AR, et al. Trial of roxithromycin in subjects with asthma and serological evidence of infection with Chlamydia pneumoniae. Am J Respir Crit Care Med 2001; 164: 536-41

115. Kamada AK, Hill MR, Iklé DN, Brenner AM, Szefler SJ. Efficacy and safety of low-dose troleandomycin therapy in children with severe, steroid-requiring asthma. J Allergy Clin Immunol 1993; 91: 873-82 
116. Kostadima E, Tsiodras S, Alexopoulos EI, Kaditis AG, Mavrou I, Georgatou N, et al. Clarithromycin reduces the severity of bronchial hyperresponsiveness in patients with asthma. Eur Respir J 2004; 23: 714-7

117. Nelson HS, Hamilos DL, Corsello PR, Levesque NV, Buchmeier AD, Bucher BL. A double-blind study of troleandomycin and methylprednisolone in asthmatic subjects who require daily corticosteroids. Am Rev Respir Dis 1993; 147: 398-404

118. Shoji T, Yoshida S, Sakamoto H, Hasegawa H, Nakagawa H, Amayasu H. Anti-inflammatory effect of roxithromycin in patients with aspirin-intolerant asthma. Clin Exp Allergy 1999; 29: 950-6

119. Sutherland ER, King TS, Icitovic N, Ameredes BT, Bleecker E, Boushey HA, et al; National Heart, Lung and Blood Institute's Asthma Clinical Research Network. A trial of clarithromycin for the treatment of suboptimally controlled asthma. J Allergy Clin Immunol 2010; 126: 747-53

120. Strunk RC, Bacharier LB, Phillips BR, Szefler SJ, Zeiger RS, Chinchilli VM, et al.; CARE Network. Azithromycin or montelukast as inhaled corticosteroid-sparing agents in moderate-to-severe childhood asthma study. J Allergy Clin Immunol 2008; 122: 1138-44

121. Szefler SJ, Rose JQ, Ellis EF, Spector SL, Green AW, Jusko WJ. The effect of troleandomycin on methylprednisolone elimination. J Allergy Clin Immunol 1980; 66: 447-51

122. Weinberger M, Hudgel D, Spector S, Chidsey C. Inhibition of theophylline clearance by troleandomycin. J Allergy Clin Immunol 1977; 59: 228-31

123. Kamada AK, Hill MR, Brenner AM, Szefler SJ. Effect of low-dose troleandomycin on theophylline clearance: implications for therapeutic drug monitoring. Pharmacotherapy 1992; 12: 98-102

124. Richeldi L, Ferrara G, Fabbri LM, Lasserson TJ, Gibson PG. Macrolides for chronic asthma. Cochrane Database Syst Rev 2005 Oct 19; (4): CD002997

125. Shinkai M, Henke MO, Rubin BK. Macrolide antibiotics as immunomodulatory medications: proposed mechanisms of action. Pharmacol Ther 2008; 117: 393-405

126. Labro MT. Cellular and molecular effects of macrolides on leukocyte function. Curr Pharm Des 2004; 10: 3067-80

127. Bosnar M, Čužić S, Bošnjak B, Nujić K, Ergović G, Marjanović N, et al. Azithromycin inhibits macrophage interleukin- $1 \beta$ production through inhibition of activator protein-1 in lipopolysaccharide-induced murine pulmonary neutrophilia. Int Immunopharmacol 2011; 11: 424-34

128. Desaki M, Takizawa H, Ohtoshi T, Kasama T, Kobayashi K, Sunazuka T, et al. Erythromycin suppresses nuclear factor-kappaB and activator protein-1 activation in human bronchial epithelial cells. Biochem Biophys Res Commun 2000; 267: 124-8

129. Ichiyama T, Nishikawa M, Yoshitomi T, Hasegawa S, Matsubara T, Hayashi T, et al. Clarithromycin inhibits NF-kappaB activation in human peripheral blood mononuclear cells and pulmonary epithelial cells. Antimicrob Agents Chemother 2001; 45: 44-7

130. Shinkai M, Foster GH, Rubin BK. Macrolide antibiotics modulate ERK phosphorylation and IL-8 and GM-CSF production by human bronchial epithelial cells. Am J Physiol Lung Cell Mol Physiol 2006; 290: L75-L85

131. Blau H, Klein K, Shalit I, Halperin D, Fabian I. Moxifloxacin but not ciprofloxacin or azithromycin selectively inhibits IL-8, IL-6, ERK1/2, JNK, and NF-kappaB activation in a cystic fibrosis epithelial cell line. Am J Physiol Lung Cell Mol Physiol 2007; 292: L343-L352

132. Abe S, Nakamura H, Inoue S, Takeda H, Saito H, Kato S, et al. Interleukin- 8 gene repression by clarithromycin is mediated by the activator protein-1 binding site in human bronchial epithelial cells. Am J Respir Cell Mol Biol 2000; 22: 51-60 